\title{
Identifying the Information Literacy Competency Standards for Teachers
}

\author{
Ruuhina Binti Mohd Sani', Arumugam Raman² \\ ${ }^{1}$ School of Education and Modern Language, Universiti Utara Malaysia \\ ${ }^{2}$ School of Education and Modern Language, Universiti Utara Malaysia \\ Corresponding Author: Ruuhina Binti Mohd Sani
}

\begin{abstract}
In line with the ministry of education to enhance students's higher order thinking skills; teachers should take advantage of ICT use in classroom. The main purpose of this conceptual paper is to discuss the elements of information literacy competence for teachers in Malaysia. The literature review on existing standard competency literacy will be basis of this discussion. The ministry want to ensure that basic ICT infrastructure are in place throughout the system and the main priority is that all teachers have basic competency in ICT. Based on proposed framework, it is presumed that there were three dimensions related to information literacy competence (knowledge, skills and attitude).
\end{abstract}

Keywords: ICT, Information literacy competence, ICT Competency Literacy Standards

\section{INTRODUCTION}

There is no doubt that technology in today society is used more widely, especially for the purpose of teaching and learning in classroom. This is proved, when modern technology nowadays offers a lot of tools that can be used in classrooms to enhance teaching and learning quality (Bruniges, 2003; Lefebvre, Deaudelin, \& Loiselle, 2006; Bingimlas, 2009; Hamidi et al., 2011; Hussain et al., 2011). ICT integration defined as the process to determine where and how technology fits in the teaching and learning situation (Rosnaini Mahmud \& Mohd Arif, 2008).
Today, everyone are able to enter the websites from everywhere at any time and use the free information provided in Internet. Worldwide research has shown that ICT able to improve students' learning as well as gives better pedagogical practices. Human society transformed from the information technology age to the knowledge age because of its on-going and rapid development (Galbreath, 2000). Hence, it is undeniable that the enormous role and potential of ICT in promoting the learning outcome with more latest of knowledge without and obstruction on accessibility and distance limitation, and yet straighten students' thinking skills (MoE, 2012). Hepp et al. (2004) state that the roles of ICT in the educational system can be pedagogical, cultural, social, professional and administrative.

In line with the on-going globalization of ICT, Malaysian education system is planned to educate students as future workforce; not only as technologysavvy also hope to be innovative and conversant in technical aspect (Ghavifekr \& Sufean, 2011). Hence, Ministry of Education Malaysia (MoE) intends to provide the best education for all students regardless of ethnicity or socioeconomic background. According to the Malaysian Education Blueprint (2013- 2025), through the sixth chapter of the Blueprint Transformation through ICT by Ministry of Education, intends to increase the impact of student learning and ensure students not only learn to use ICT but also can use it 
effectively. The ministry has allocated a huge amount to achieve those goals. However, based on the study of the teachers competence level that have been conducted, indicate that the level of teachers competence is still limited, (MoE, 2012). A survey conducted by UNESCO (2012) found no evidence that ICT being used in classroom to foster either student's creativity, problem-solving, critical thinking nor communication skills. After in-depth study continued, the reason given as to why it happens is because training and support services such as technicians to maintain the ICT tools are not sufficient.

In addition, other issues raised was the lack of long-term strategy to maintain and upgrade the main elements of policy implementation such as ICT infrastructure and teacher competence. The ministry of education continues to aim for all schools to official y qualify as "Smart Schools" in order to achieve minimum standards of ICT utilization, capability, infrastructure availability and application while integrating ICT in learning process (MoE, 2012). Among the steps taken is to ensure the basic needs of ICT are provided. Hence, critical elements to use ICT such as devices, network and applications, teacher's ICT competencies also curriculum and assessment must be in place before the more excruciating and innovative use of ICT can be executed. In improving ICT literacy among teachers, a lot of teachers' professional development programmes related to the implementation of ICT was organized to ensure the changes in teaching practices especially in integrating ICT in teaching more effectively. Besides, the ministry will enhance the training programmes for teachers so that it will meet a minimum level of ICT literacy by the end of 2015. Based on study by Fong et al. (2013), most of the courses included in training programmes lack of uniformity and curricula. In addition, they were designed by organizers did not follow any ICT competency standards. Hence, the needs for training programmes to meet the competencies set in competency standards are important.

\section{Defining information literacy competence in educational context}

Bruce (2000) and Doyle (1994)

define information literacy as

individual's ability that includes skills in managing information and the knowledge in applying that information. The definition of information literacy been defines among scholars from many different perspective. The most widely known was proposed by American Library Association (ALA) in 1989. ALA defined information literacy as the ability to recognize what and when information is needed, and how to acquired, evaluate and utilize that information effectively. With respect to "competency", it is defined as an individual's ability to perform, such as the possession of knowledge, skills and personal characteristics needed to satisfy the requirements of a situation (ALA, 2000). Information literacy competence defined as a set of related knowledge, skills and attitudes that can be influenced by training and learning, and it allow individuals to perform given task effectively in order to achieve the standard specified in their work (Mandl \& Kraus, 2003; Klein, Spector, Grabowski \& de la Teja, 2004; Raman, Ying , \& Khalid, 2015). Based on the above definition, one can conclude that the information literacy competence of teacher is the possession of necessary knowledge, skills and attitudes to effectively acquired, evaluate and utilize those information to solve problems when they practice teaching.

The impact of ICT application depends on the capacity of teachers to exploit the efficiently in learning pedagogy. However, there are factors that beyond teachers' control such as culture, institutions' leadership, curriculum and assessment (Ramboll Management, 2006; Ramboll Management, 2005). Through ICT, teacher also be able to improve teaching by 
improve the existing technology or introduce a better way for teaching and learning (Balanskat, Blamire \& Kefala, 2006). These are some method that allows teachers to exploit ICT efficiently.

Information literacy competency standards today shares the same principle which is, information literacy skills is continuity in terms of the capacity of individual efforts that requires in different levels. In education, the development of information literacy begins at an early stage and the process continues through the higher learning and until adulthood (UNESCO, 2008). In more advanced societies, information literacy skills developed in conjunction with ICT skills as digital technology and the electronic database is the main source of information. Thus, an individual requires a combination of cognitive and technical skills (competence) to access and use information.

Kitschner and Davis (2003) identified there are some competences required by teachers to utilize ICT in their learning environment. These competences include: teachers competence to make personal use of ICT in learning, competence to control various educational paradigms that make use of ICT in learning, enough competence to exploit ICT as mind tools, competence to make use of ICT in classroom as a tool for teaching, competence in understanding the policy dimensions of ICT use in classroom for teaching and learning purpose.

\section{Theories and models related to information literacy competence in education}

\section{Constructivist learning theory}

Till today, the emergence of ICT in instructional technology has been coincided with the increasing awareness and recognition of alternative theories for learning. Most of past study on information literacy is dominated by constructivists who are emphasizing those individuals, as active builders of meaning and they should be independent and self-sufficient.
(Tuominen et al., 2005). Constructivism approaches information literacy by learning how individual required information, seeking the information and the relevance criteria of individuals are affected or directed by their current emotional and cognitive states, situations and tasks. Typically, the traditional approach that requires teachers presented certain problems to the student to enable them to repeat steps that have been shown by teacher before. However in constructivism student need to control elements (i.e.: using multimedia) in the learning environment, even better thereby (Mayer \& Moreno, 2002).

\section{Technological Pedagogical Content Knowledge (TPACK)}

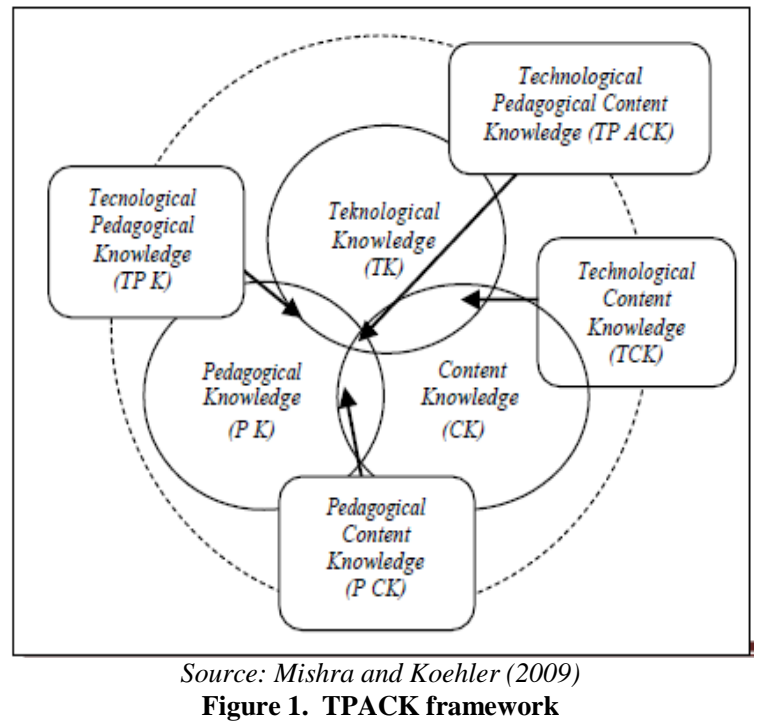

Contrary to the views expressed in the theory of constructivism, process to integrate technology, content and pedagogy to develop technological pedagogical content knowledge (TPACK) is easy (Koehler \& Mishra, 2009). The teaching process using TPACK is critical in the competency literacy ICT development for new generations of teachers in the future. To enable real changes made in ICT education, leaders need to be trained among educators and teachers (Doyle \& Reading, 2012). In TPACK model, the role of education and teachers is very important in realizing the changes to ICT education in educational system. Nore, Engelien \& 
Johannesen (2010) also stated that TPACK is useful in understand and manage teaching practices and also to determine the need for competence among teachers and school management (Nore et al., 2010).

\section{Review on existing information literacy competence standards}

The main objective of ICT literacy standards constructed is as a guide for teachers' education faculty in developing literacy instruction for preservice teachers. The second objective is to enable the measurement and evaluation of teaching and curriculum based on benchmarks that have been set (Education and Behavioral Science Section, 2011).

\section{Malaysian Teachers Standards (MTS)}

Many developed countries such as the United Kingdom, Japan and Australia has introduced and implemented competency standards in their educational system. But, according to Saedah Siraj and Mohammed Sani Ibrahim (2012), up until now, Malaysia still do not have our own ICT's competency standards for teachers. However, there have been efforts to develop new competency standards for teachers known as Malaysian Teacher Standard (MTS). This standards set out the professional competence needed to be achieved by teachers; and the requirement that training agencies and institutions should follow to help teachers achieve the specified level of competence (Teacher Training Division, 2009). The standards developed to identify the level of teachers' competence in teaching professionalism, knowledge and understanding, as well as teaching and learning skills. However, these standards did not elaborate intensively on ICT in education, especially ICT literacy competence.

\section{National Education Technology Standards (NETS)}

ISTE is the non-profit organization specializing in teacher's technology education. One of the organization purposes are to develop, implement and integrate technology standards to facilitate learning. The National Educational Technology Standards for teacher also known as NETS$\mathrm{T}$ is focuses on pre-service teacher education. According to ISTE (2008), before, teachers have always held the key to student success and now their role is changing. The ISTE standards define the new skills and pedagogical insights educators need to teach, work and learn in the digital age. This standard has helped almost all states in the United States by applying technology to facilitate learning. Below are the lists of competencies based on NETS-T standard:

1. Technology operations and concepts,

2. Planning and designing learning environments and experiences,

3. Teaching, learning and curriculum,

4. Assessment and evaluation,

5. Productivity and professional practice

6. Social, ethical, legal, and human issues

\section{ICT Competency Standards for Teachers (ICT-CST) UNESCO}

The ICT-CST proposed to help countries in developing comprehensive national teacher ICT policies and standards. In addition it should be seen as an important component for ICT scope in Education Master Plan (UNESCO, 2008). It is also as guidelines for designing teacher education and training program that will prepare and facilitate their professional development in integrate effective ICT pedagogical (UNESCO, 2008). ICT-CST is arranged in three different approaches or stages in teachers' development. The first stage is 'Technology Literacy' which enable students to integrate ICT in order to learn more efficiently. The second stage is 'Knowledge Deepening' which enable students to acquire knowledge of their curriculum that more profound and apply that knowledge to complex. Real-world problems. The last stage is 'Knowledge Creation' which enable students, society and the workforce they become, to create 
new knowledge for better society. Based on ICT-CST, by crossing six aspects of teacher's work (policy, curriculum, pedagogy, ICT, organization and teacher training) with three approaches to teaching (technology literacy, knowledge deepening and knowledge creation) based on human capacity development will create 18 modules for information literacy competencies.

\section{Australian and New Zealand Information Literacy Framework}

The framework provides the principles, standards and practice that can support information literacy education in all education sectors (Australian and New Zealand Institute for Information Literacy (ANZIL), 2004). Based on this framework information literate enable people to:

identify the need for information

determine the extent of information needed

access the information needed efficiently

evaluate the information required and its sources critically

manage the information required

work with the selected information based on their knowledge

use the information required to learn, solve problems and make decision

- understand the legal, social and legal issues that involved in information use

The framework incorporates standards and learning outcomes including the characteristics, attributes, processes, knowledge, skills, attitudes, beliefs and aspirations that involve information literate person (ANZIL, 2004). These standards developed based on the generic skills, information skills and; values and beliefs. Generic skills will involve ability to solve problems, collaboration and teamwork, communication and also critical thinking. Information skills will involve the ability to search the information, use the information and information technology fluency. Values and beliefs will involve the ability to use information wisely and ethically, be responsibility to community and participate with the community. These are all the learning dimension combined in information literacy.

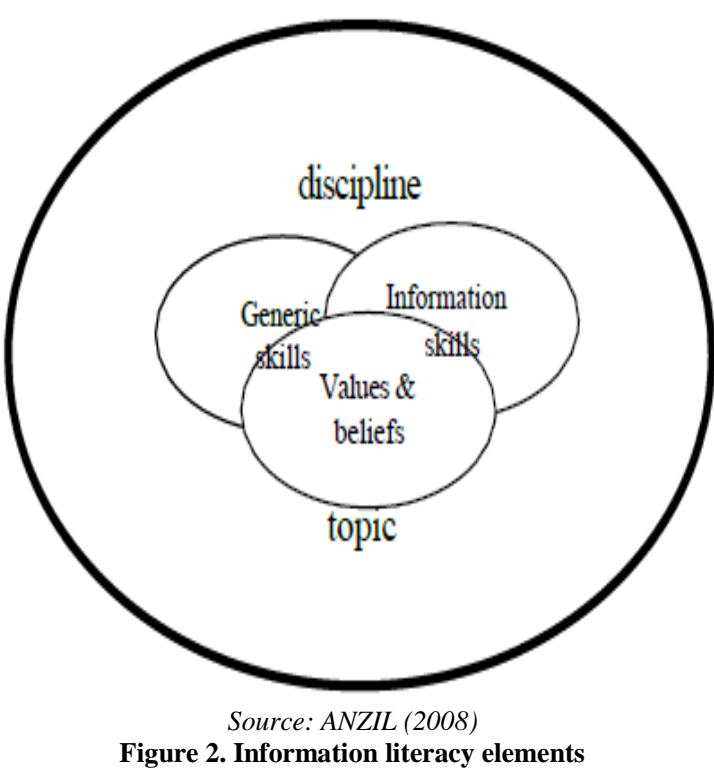

The framework provides educational institutions guidance whenever they need to develop policy within disciplines.

\section{Elements of information literacy competence based on existing standards}

According to Wen and Shih (2008) information literacy competence of a teacher is the possession of knowledge, skills and attitudes to collect, analyze, assess, organize and synthesize information effectively to solve problem in work. Based on literature on existing standards, one can conclude that the elements of information literacy competencies are the combination of two:

1) dimensions (knowledge, skills and attitudes)

In regards with knowledge, one should be able to understand the characteristic of information, be familiar on how to search for information, and must possess the ability to access, organize, synthesize the information. In regards with skills, one should be possess the 
basic skills in information technology, be able to utilize tools and systems when retrieve information, process and convey the information. In regards with attitudes one should be able to appreciate the value and power of information technology can enhance the teaching and learning.

2) use of information technology

\section{CONCLUSION}

Derived from the literature above, a teacher's information literacy competence should include three dimensions which are knowledge, skills and attitudes. Even though, most of the standards more focused on knowledge and skills but Wen and Shih (2008) believes that the attitudes dimension have great impact on behaviors that determine the results of actions because if a teacher possess certain knowledge and skill about technology, they will not use it effectively if they lack of positive attitude towards technology. Hence, the attitudes dimension is important factor that need to be consider in discussing the information literacy competence.

\section{ACKNOWLEDGEMENT}

This work was supported by the Ministry of Higher Education, Malaysia under FUNDAMENTAL RESEARCH GRANT SCHEME (FRGS) (So Code:13037).

\section{REFERENCES}

1. Australian and New Zealand Institute for Information Literacy and Council of Australian University Librarians (ANZIL) (2004). Australian and New Zealand information literacy framework. Principles, standards and practice. Adelaide, Australian Council for Adult Literacy. Wen, J. R., \& Shih, W. L. (2008). Exploring the information literacy competence standards for elementary and high school teachers. Computers \& education, 50(3), 787-806.

2. Balanskat, A., Blamire, R., \& Kefala, S. (2006). The ICT impact report.European Schoolnet.
3. Bingimlas, K. A. (2009). Barriers to the successful integration of ICT in teaching and learning environments: A review of the literature. Eurasia Journal of Mathematics, Science \& Technology Education, 5(3), 235-245.

4. Bruce, C. (2000). Information literacy research: dimensions of the emerging collective consciousness. Australian Academic \& Research Libraries, 31(2), 91-109.

5. Bruniges, M. (2003). Developing performance indicators for ICT use in education: Australia's experience, online document.

6. Doyle, C. S. (1994). Information literacy in an information society: A concept for the information age. Diane Publishing.

7. Doyle, H., \& Reading, C. (2012). Building teacher educator TPACK:

Developing leaders as a catalyst for change in ICT Education. Future challenges, sustainable futures, 272- 282.

8. Education and Behavioral Science Section (EBSS). (2011). Information literacy standard for teacher education: EBSS instruction for educators committee 20062007 and 2010-2011. Chicago: ACRL Board of Directors at the Spring Executive Committee Meeting May 11, 2011. Retrieved from URL:

http://www.ala.org/acrl/sites/ala.org. acrl/files/content/standards/ilstandard s_te.pdf

9. Fong, S. F., Ch'ng, P. E. \& Ping, P. F. (2013). Development of ICT competency satndard using the Delphi technique.

10. Galbreath, J. (2000). Knowledge management technology in education: An overview. Educational Technology, 40(5), 28-33.

11. Ghavifekr, S., \& Hussin, S. (2011). Managing Systemic Change in a Technology-based Education System: A Malaysian Case Study. Procedia-Social and Behavioral Sciences, 28, 455-464.

12. Lefebvre, S., Deaudelin, D., \& Loiselle, J. (2006, November). ICT implementation stages of primary school teachers: The practices and conceptions of teaching and learning. In Australian 
Association for Research in Education National Conference, Adelaide, Australia.

13. Hamidi, F., Meshkat, M., Rezaee, M., \& Jafari, M. (2011). Information technology in education. Procedia Computer Science, 3, 369-373.

14. Hepp, P., Hinostroza, J. E., Laval, E., \& Rehbein, L. (2004). Technology in schools: Education, ICT and the knowledge society (pp. 30-47). World Bank, Distance \& Open Learning and ICT in Education Thematic Group, Human Development Network, Education.

15. Hussain, A. J., Morgan, S., \& Al-Jumeily, D. (2011, December). How Does ICT Affect Teachings and Learning within School Education. In Developments in Esystems Engineering (DeSE), 2011 (pp. 250- 254). IEEE.

16. Rosnaini Mahmud \& Mohd Arif. $\mathrm{Hj}$. Ismail. (2008). Factors influencing ICT integration in the classroom: Implication to teacher education. EABR \& TLC Conference Proceeding. Austria.

17. Ministry of Education Malaysia. (2012). Preliminary Report Malaysia Education Blueprint 2013-2025. Retrieved November, 4, 2012.

18. ISTE. (2008), ISTE National Educational Technology Standards (NETS) and Performance Indicators for Teachers, ISTE, Eugene, OR.(2014, Oktober 10) dicapai daripada: http://cnets.iste.org/tssa/

19. Kirschner, P., \& Davis, N. (2003). Pedagogic benchmarks for information and communications technology in teacher education. Technology, Pedagogy and Education, 12(1), 125-147.

20. Klein, J. D., Spector, J. M., Grabowski, B., \& de la Teja, I. (2004). Instructor Competencies: Standards For Face- ToFace, Online And Blended Seting. Greenwich, CT: Information Age Publishing.

21. Koehler, M., \& Mishra, P. (2009). What is technological pedagogical content knowledge (TPACK)?. Contemporary issues in technology and teacher education, 9(1), 60-70.
22. Mandl, H., \& Krause, U. M. (2003). Learning competence for the knowledge society. Toward the virtual university: International online perspectives, 65-86.

23. Malaysia, K. P. (2012). Preliminary Report Malaysia Education Blueprint 2013-2025. Retrieved November, 4, 2012.

24. Mayer, R. E., \& Moreno, R. (2002). Animation as an aid to multimedia learning. Educational psychology review, 14(1), 87-99.

25. Nore, H., Engelien, K., \& Johannesen, M. (2010). TPACK as shared, distributed knowledge. In Proceedings of Society for Information Technology \& Teacher Education International Conference (pp. 3920-3925).

26. Raman, A., Ying, L. T., \& Khalid, R. (2015). The relationship between culture and organizational commitment among Chinese primary school teachers. Mediterranean Journal of Social Sciences, 6(2 S5), 93.

27. Ramboll Management (2005) "The use of ICT for learning and teaching in initial Vocational Education and Training", Study for the European Commission DG Education and Culture, November 2005. http://ec.europa.eu/education/programmes /elearning/doc/studies/ict_in_ vocational_en.pdf

28. Ramboll Management (2006). Elearning Nordic 2006: Impact of ICT on Education, Denmark: Ramboll Management. Accessed at: http://www.skolutveckling.se/skolnet /english/pdf/English_eLearning\%20 Nord ic_Print.pdf\#search=\%22Elearning\% 20Nordic\%202006\% 22.

29. Rosnaini Mahmud \& Mohd Arif. Hj. Ismail. (2008). Factors influencing ICT integration in the classroom: Implication to teacher education. EABR \& TLC Conference Proceeding. Austria.

30. Saedah Siraj, \& Mohammed Sani Ibrahim, (2012). Standard Kompetensi Guru Malaysia. In Prosiding Seminar Majlis Dekan Pendidikan IPTA.

31. Tuominen, K., Savolainen, R., \& Talja, S. (2005). Information Literacy as a Sociotechnical Practice 1. The Library Quarterly, 75(3), 329-345. 
32. UNESCO (2008). ICT competency standards for teachers: Competency standards modules. UK: United Nations Educational, Scientific and Cultural Organization.

33. Wen, J. R., \& Shih, W. L. (2008). Exploring the information literacy competence standards for elementary and high school teachers. Computer

How to cite this article: Ruuhina Binti Mohd Sani, Raman A. Identifying the information literacy competency standards for teachers. International Journal of Research and Review. 2021; 8(2): 119-126. 